\title{
Latihan Aerobik Untuk Meningkatkan Koaitas Hidup Pada Lansia
}

\author{
${ }^{1}$ Setyarin Pebriyuani Pamungkas, ${ }^{2}$ Widya Munawwarah, ${ }^{3}$ Nila Kumala Dewi, ${ }^{4}$ Mufidah \\ Nurdesia
}

Program Studi D IV Fisioterapi, Jurusan Fisioterapi, Poltekkes Kemenkes Jakarta III

Jl. Melati 2 No. 15, RT 001/RW 009, Jatiwarna, Kec. Pd Melati, Kota Bks, Jawa Barat 17415Email :

setyarinpebriyuani13@gmail.com

\begin{abstract}
ABSTRAK
Latar Belakang: Lansia adalah seseorang yang telah mencapai usia 60 tahun ke atas. Lansia di Indonesia pada tahun 2018 sekitar 24,49 juta $(9,27 \%)$ dan diperkirakan pada tahun 2045 jumlahnya meningkat menjadi 63,31 juta. Kondisi tua (lansia) akan cenderung mengalami banyak permasalahan fisik, psikis, sosial, maupun finansial. Dalam upaya peningkatan kesehatan lansia, khususnya pada peningkatan kualitas hidup dapat dilakukan dengan meningkatkan gaya hidup sehat kehidupan sehari - hari. Dengan meningkatnya angka harapan hidup, aerobic exercise dapat memberikan dampak positif dalam meningkatkan kualitas hidup pada lansia. Tujuan : Penelitian ini bertujuan untuk mengetahui aerobic exercise berpengaruh terhadap peningkatan kualitas hidup pada lansia. Metode: penelitian ini menggunakan metode systematic literature review dengan mengkaji 5 literatur eligible yang diterbitkan dengan rentang waktu 2011 - 2021. Literatur yang didapatkan berasal dari 3 search engine, yaitu PubMed, Reaserch Gate, dan Semantic Scholar dengan metode PICOS, kemudian di seleksi dengan kuesioner dan diekstraksi menggunakan diagram PRISMA. Hasil: Terdapat 5 literatur menggunakan desain reandomized controlled trial. Alat ukur yang digunakan yaitu SF-36. Secara keseluruhan $\mathrm{p}-$ value dengan $(\mathrm{P}<0.05)$. dari kelima literatur menunjukkan bahwa terdapat peningkatan kualitas hidup. Kesimpulan: Terdapat adanya peningkatan kualitas hidup pada lansia dengan intervensi aerobic exercise. Kata kunci: aerobic exercise; lansia; kualitas hidup
\end{abstract}

\section{ABSTRACT}

Background: Elderly is someone who has reached the age of 60 years and over. The elderly in Indonesia in 2018 was around 24.49 million (9.27\%) and it is estimated that in 2045 the number will increase to 63.31 million. The condition of the elderly (elderly) will tend to experience many physical, psychological, social, and financial problems. To improve the health of the elderly, especially in improving the quality of life, it can be done by increasing a healthy lifestyle in daily life. With increasing life expectancy, aerobic exercise can have a positive impact on improving the quality of life in the elderly. Purpose: This study aimed to determine the effect of aerobic exercise on improving the quality of life in the elderly. Research Methods: This type of research was a systematic literature review method by reviewing 5 eligible pieces of literature published with the period 2011 - 2021. The literature obtained comes from 3 search engines PubMed, Research Gate, and Semantic Scholar with the PICOS method, then selected by questionnaire. and extracted using PRISMA diagram. Results: 5 literature are using a randomized controlled trial design. The measuring instrument used is SF-36. Overall $p$ value with ( $p<0.05)$. from the 5 literature shows that there is an increase in the quality of life. Conclusion: There is an improvement in the quality of life in the elderly with aerobic exercise intervention.

Keywords: aerobic exercise; elderly; quality of life

July $31^{\text {th }}$, 2021 on zoom cloud meeting

Muhammadiyah University of Surakarta, Central Java, Indonesia 
S.P Pamungkas, W Munawwarah, N. K Dewi \& M Nurdesia Fisiomu.2021 Vol 2(3): 175-188 DOI: $10.23917 /$ fisiomu.v2i3.15203

\section{Pendahuluan}

Lansia merupakan seseorang yang telah mencapai usia 60 tahun ke atas, menurut Peraturan Pemerintah Republik Indonesia Nomor 43 tahun 2004. World Health Organization (WHO) membagi lansia menjadi 4 kelompok yaitu, usia pertengahan (middle age) adalah 45- 59 tahun, lanjut usia (elderly) adalah 60-74 tahun, lanjut usia tua (old) adalah 75-90 tahun, dan usia sangat tua (very old) di atas 90 tahun. Dalam waktu 50 tahun populasi lansia di dunia akan mengalami peningkatan 3 kali lipat, dari 600 juta individu pada tahun 2000, menjadi 2 milliar pada tahun 2050 (Suyanto, Paskaria and Gunawan, 2021)

Indonesia sebagai negara berkembang sedang menghadapi transisi demografis. Transisi demografi menyebabkan penurunan proporsi balita dan peningkatan proporsi lansia yang berusia 60 tahun ke atas. Kondisi ini menyebabkan proporsi penduduk lanjut usia akan lebih tinggi dibandingkan dengan penduduk balita. Kondisi ini disebabkan oleh turunnya angka kesuburan total (TFR) dan peningkatan angka harapan hidup (AHH) (Hidayati, Gondodiputro and Rahmiati, 2018).

Angka harapan hidup (AHH) mengindikasikan derajat kesehatan masyarakat dan mencerminkan tingkat keberhasilan pembangunan bidang kesehatan. Semakin tinggi AHH maka derajat kesehatan masyarakat semakin baik dan hal ini didukung oleh keberhasilan dalam pembangunan bidang kesehatan (Maryani and Kristiana, 2018).

Lansia di Indonesia pada tahun 2018 sekitar 24,49 juta $(9,27 \%)$ dan diperkirakan pada tahun 2045 jumlahnya meningkat menjadi 63,31 juta. Badan Pusat Statistik (BPS) memperkirakan pada tahun 2045 Indonesia akan memiliki hampir 63,31 juta lansia. Angka harapan hidup untuk perempuan lebih tinggi bila dibandingkan dengan laki-laki. Hal ini dapat dilihat dari jumlah lansia perempuan $(9,53 \%)$ yang lebih banyak daripada lansia laki-laki sebesar $(8,54 \%)$. Populasi lansia di Indonesia diprediksi akan terus meningkat sehingga Indonesia menjadi salah satu negara yang berstruktur tua (aging population). (Suyanto, Paskaria and Gunawan, 2021).

Menjadi tua merupakan suatu proses natural, penuaan akan terjadi pada semua sistem tubuh manusia dan tidak semua sistem akan mengalami kemunduran pada waktu yang sama. Kondisi tua (lansia) akan cenderung mengalami banyak permasalahan fisik, psikis, sosial, maupun finansial (Fatmawati and Imron, 2017). Permasalahan yang terjadi pada lansia akan meningkat seiring bertambahnya usia yang akan memengaruhi kualitas hidup lansia (Kiik, Sahar and Permatasari, 2018).

WHO mendefinisikan kualitas hidup (QOL) sebagai sistem nilai dan budaya yang selaras dengan tujuan individu di mana seseorang hidup, relatif terhadap tujuan, harapan, standar hidup, dan minat mereka. Ini adalah konsep terperinci yang menggabungkan kesehatan fisik dan psikologis individu, tingkat kemandirian mereka, hubungan sosial mereka dan bagaimana mereka berhubungan dengan lingkungan sekitarnya. (Ruzevicius, 2016)

Menurut World Health Organization, terdapat empat domain mengenai kualitas hidup yang meliputi domain kesehatan fisik, psikologis, domain hubungan sosial, dan domain lingkungan. Keempat domain tersebut diidentifikasikan sebagai suatu perilaku, status, keberadaan, kapasitas, potensial, dan persepsi serta pengalaman subjektif (Ekawati et al., 2020). Domain kesehatan fisik dapat memengaruhi kemampuan individu untuk melakukan aktivitas. Kondisi fisik yang semakin rentan menyebabkan seorang lansia merasa kehidupannya sudah tidak berarti lagi dan putus asa dengan kehidupan yang saat ini dijalani. Hal 
S.P Pamungkas, W Munawwarah, N. K Dewi \& M Nurdesia Fisiomu.2021 Vol 2(3): 175-188

DOI: $10.23917 /$ fisiomu.v2i3.15203

ini merupakan salah satu tanda rendahnya kualitas hidup lanjut usia yang dikarenakan lansia tidak dapat menikmati masa tuanya. Demikian, pelayanan kesehatan bagi lansia sangat menuntut perhatian, agar lansia dapat menghabiskan sisa usia dengan optimal (Setianingsih, 2018).

Upaya peningkatan kesehatan lansia, khususnya pada peningkatan kualitas hidup dapat dilakukan dengan meningkatkan gaya hidup sehat kehidupan sehari - hari. Gaya hidup sehat dapat dilakukan dengan melakukan berbagai program, salah satunya dengan melakukan latihan secara rutin yang tentunya memiliki efek cukup positif pada kualitas hidup seseorang, khususnya pada lansia. Latihan juga dapat menjadi salah satu alternatif atau pelengkap sebagai terapi bagi lansia yang memiliki masalah kualitas hidup yang rendah (Pamungkas, 2016).

Fisioterapi berperan dalam meningkatkan kualitas hidup pada lansia dengan memberikan pelayanan kesehatan yang ditujukan kepada masyarakat untuk mengembangkan, memelihara dan memulihkan gerak dan fungsi tubuh sepanjang rentang kehidupan dengan peningkatan gerak, peralatan (fisik, elektroterapeutis dan mekanis) pelatihan fungsi, dan komunikasi (Peraturan Menteri Kesehatan RI Nomor 65 Tahun 2015).

Salah satu teknologi fisioterapi untuk meningkatkan kualitas hidup pada lansia adalah dengan exercise. Fungsi fisik dapat di tingkatkan dengan exercise, selain itu exercise dapat meningkatkan kemampuan melakukan aktivitas kehidupan sehari-hari. Beberapa bukti menunjukkan bahwa latihan fisik, terutama latihan aerobik dapat meningkatkan sistem oksigen, meningkatkan kebugaran kardiorespirasi, kekuatan otot, dan kesejahteraan fisik pada lansia (Knips et al., 2019). Latihan aerobik merupakan dasar dari pelatihan ketahanan, yang ditandai dengan pengeluaran energi yang moderat dalam jangka waktu yang lama. (Wilson et al., 2013)

Latihan aerobik mengacu pada jenis aktivitas fisik terstruktur yang berulang yang membutuhkan sistem metabolisme tubuh untuk menggunakan oksigen untuk menghasilkan energy, dan meningkatkan kapasitas sistem kardiovaskular untuk mengambil dan mengangkut oksigen. Aktivitas aerobik dapat dilakukan dalam berbagai bentuk, dengan ciri umum yang dicapai pada detak jantung $70-80 \%$ dari jumlah maksimum yang sesuai dengan usia seseorang.(Wilson et al., 2013)

Aerobic exercise meningkatkan kemampuan otot untuk menggunakan energi secara langsung, peningkatan enzim oksidatif dalam otot, peningkatan densitas dan ukuran mitokondria, serta peningkatan suplai kapiler serabut otot. selain itu juga menghasilkan adaptasi kardiovaskuler sehingga daya tahan individu meningkat (Zeng et al., 2018). Latihan aerobik yang dilakukan pada populasi lanjut usia akan meningkatkan kebugaran secara umum (General Physical Fitness) yang ditandai dengan daya tahan kardiorespirasi, kekuatan otot dan otot serta meningkatkan kelenturan dan Endurance Body Composition. Sedangkan pengaruh latihan aerobik terhadap otak berpengaruh positif terhadap kemampuan kognitif. Efek tersebut meliputi peningkatan faktor neutrofik, serotonin, densitas kapiler dan neurogenesis (Doewes, M, 2009).

Beberapa penelitian membuktian bahwa pemberian latihan aerobik memberikan dampak positif terhadap peningkatan kualitas hidup ada lansia, salah satunya adalah penelitian yang di lakukan oleh Wanderley et al., tahun (2015) dengan judul -Aerobic Versus Resistance Training Effects on Health-Related Quality of Life, Body Composition, and Function of Older Adults $\|$ didapatkan $p$ value $=0.01$ pada 
S.P Pamungkas, W Munawwarah, N. K Dewi \& M Nurdesia

Fisiomu.2021 Vol 2(3): 175-188

literatur sisa seleksi awal berjumlah 5 literatur.

DOI: $10.23917 /$ fisiomu.v2i3.15203

Lalu dilakukan seleksi metodologi dan tidak terdapat literatur yang dikeluarkan. Kemudian dilakukan pemeriksaan duplikasi menggunakan aplikasi manajer referensi mendeley, dan tidak terdapat literatur yang terduplikasi sehingga menghasilkan literatur yang sesuai dengan kriteria inklusi dan eksklusi sebanyak 5 lieteratur. Proses pencarian literatur yang dilakukan terdapat pada gambar 1. berikut ini.

Gambar 1. Diagram Alur Pencarian Literatur

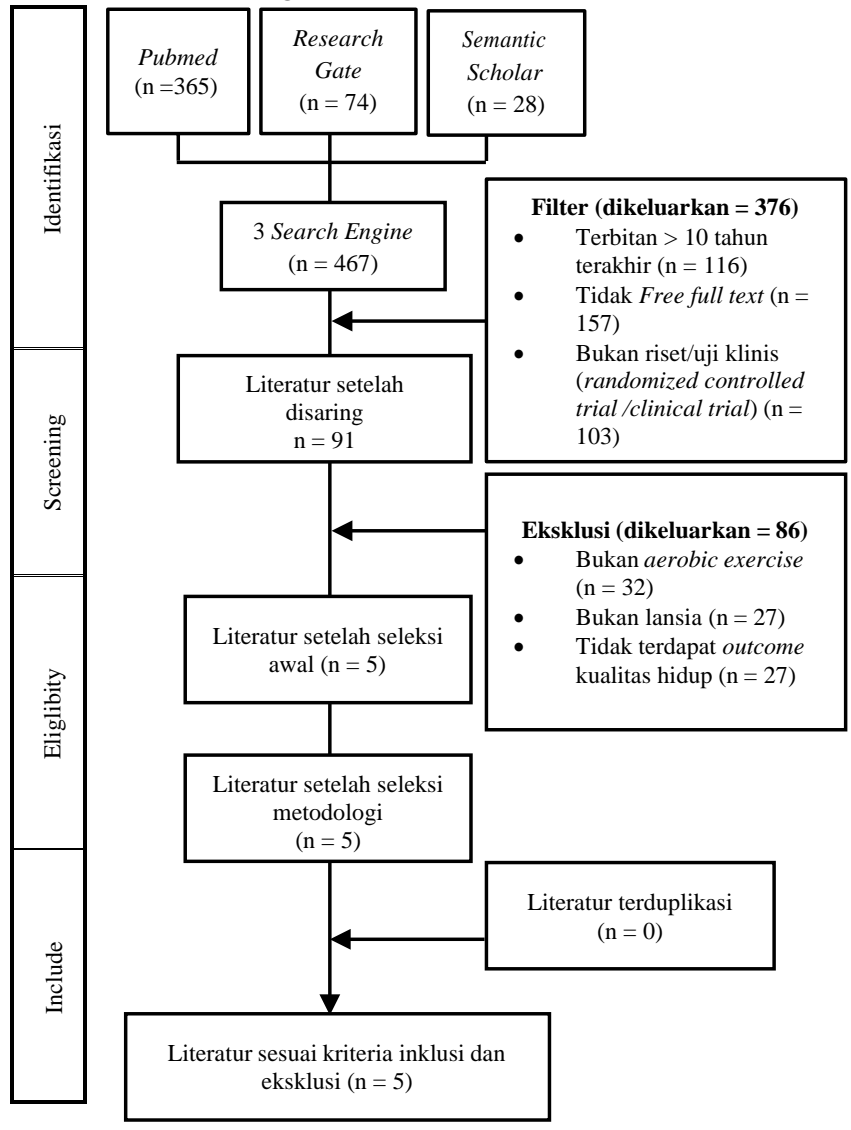

\section{Hasil Ekstraksi Data}

Setelah dilakukan cek duplikasi dengan aplikasi manajer referensi mendeley, seluruh literatur yang ditemukan diekstraksi menggunakan tabel ekstraksi data. Hasil ekstraksi data terdapat pada tabel 1 dibawah ini.

Tabel 1. Ekstraksi Data

\begin{tabular}{|c|c|c|c|}
\hline No. & Uraian & $\underset{\mathbf{h}}{\text { Jumla }}$ & $\begin{array}{c}\text { Persenta } \\
\text { se }\end{array}$ \\
\hline 1. & \multicolumn{3}{|c|}{ Desain penelitian } \\
\hline & $\begin{array}{l}\text { Randomized Controlled } \\
\text { Trial }\end{array}$ & 5 & $100 \%$ \\
\hline 2. & \multicolumn{3}{|c|}{ Besar sampel } \\
\hline & $\mathrm{N}=1-100$ & 4 & $80 \%$ \\
\hline & $\mathrm{N}=101-200$ & 1 & $20 \%$ \\
\hline 3. & \multicolumn{3}{|c|}{ Usia sampel } \\
\hline & $40-63$ tahun & 1 & $20 \%$ \\
\hline & $60-70$ tahun & 1 & $20 \%$ \\
\hline & $>60$ tahun & 2 & $40 \%$ \\
\hline & $>70$ tahun & 1 & $20 \%$ \\
\hline 4. & \multicolumn{3}{|c|}{ Perlakuan } \\
\hline & \multicolumn{3}{|l|}{ Kelompok intervensi } \\
\hline & - Aerobic exercise & 4 & $80 \%$ \\
\hline & $\begin{array}{l}\text { - Aerobic execise }+ \\
\text { music }\end{array}$ & 1 & $20 \%$ \\
\hline & \multicolumn{3}{|l|}{ Kelompok kontrol } \\
\hline & $\begin{array}{l}\text { - Tidak diberikan } \\
\text { intervensi apapun }\end{array}$ & 4 & $80 \%$ \\
\hline & - Aerobic exercise & 1 & $20 \%$ \\
\hline & \multicolumn{3}{|l|}{ Kelompok pembanding } \\
\hline & - Resistance training & 1 & $20 \%$ \\
\hline & $\begin{array}{l}\text { - Tidak ada kelompok } \\
\text { pembanding }\end{array}$ & 4 & $80 \%$ \\
\hline 5. & \multicolumn{3}{|c|}{ Dosis intervensi } \\
\hline & \multicolumn{3}{|l|}{ Dosis latihan } \\
\hline & - 40 menit & 1 & $20 \%$ \\
\hline & - 40 menit & 1 & $20 \%$ \\
\hline & - 50 menit & 3 & $60 \%$ \\
\hline & \multicolumn{3}{|l|}{ Frekuensi latihan } \\
\hline & - 2x perminggu & 1 & $20 \%$ \\
\hline & - 3x perminggu & 3 & $60 \%$ \\
\hline & - 4x perminggu & 1 & $20 \%$ \\
\hline & \multicolumn{3}{|l|}{ Lama intervensi } \\
\hline & - 8 minggu & 2 & $40 \%$ \\
\hline & - 10 minggu & 1 & $20 \%$ \\
\hline & - 6 bulan & 1 & $20 \%$ \\
\hline & - 8 bulan & 1 & $20 \%$ \\
\hline 6. & \multicolumn{3}{|c|}{ Cara ukur } \\
\hline & - SF-36 & 5 & $100 \%$ \\
\hline & $\begin{array}{l}\text { - Electronic weight } \\
\text { scale (SECA 708) }\end{array}$ & 1 & $20 \%$ \\
\hline & - Dynamometer & 1 & $20 \%$ \\
\hline & - Accelerometers & 1 & $20 \%$ \\
\hline & $\begin{array}{l}\text { - Women's Health } \\
\text { Questionnare (WHQ) }\end{array}$ & 1 & $20 \%$ \\
\hline
\end{tabular}

July $31^{\text {th }}$, 2021 on zoom cloud meeting

Muhammadiyah University of Surakarta, Central Java, Indonesia 
S.P Pamungkas, W Munawwarah, N. K Dewi \& M Nurdesia Fisiomu.2021 Vol 2(3): 175-188

\begin{tabular}{|c|c|c|c|}
\hline & - $2 \mathrm{~km} \mathrm{Walk} \mathrm{Test}$ & 1 & $20 \%$ \\
\hline & - Body composition & 1 & $20 \%$ \\
\hline & - Spirobank-G & 1 & $20 \%$ \\
\hline & - FMS & 1 & $20 \%$ \\
\hline & - Tensi digital & 1 & $20 \%$ \\
\hline & - Total cholesterol & 1 & $20 \%$ \\
\hline \multirow[t]{7}{*}{7.} & \multicolumn{3}{|c|}{ Analisa data } \\
\hline & \multicolumn{3}{|l|}{ Univariat } \\
\hline & - Mean & 5 & $100 \%$ \\
\hline & \multicolumn{3}{|l|}{ Bivariat } \\
\hline & - ANOVA & 2 & $40 \%$ \\
\hline & - ANCOVA & 2 & $20 \%$ \\
\hline & - Mann Whitney U & 1 & $20 \%$ \\
\hline
\end{tabular}

DOI: $10.23917 /$ fisiomu.v2i3.15203 
S.P Pamungkas, W Munawwarah, N. K Dewi \& M Nurdesia

Fisiomu.2021 Vol 2(3): 175-188

DOI: $10.23917 /$ fisiomu.v2i3.15203

Tabel 2. Karakteristik Literatur

\begin{tabular}{|c|c|c|c|c|c|}
\hline No. & $\begin{array}{c}\text { Penulis/Judul/Jurn } \\
\text { al/Desain Studi }\end{array}$ & Partisipan & Perlakuan & Cara ukur & Hasil \\
\hline 1. & 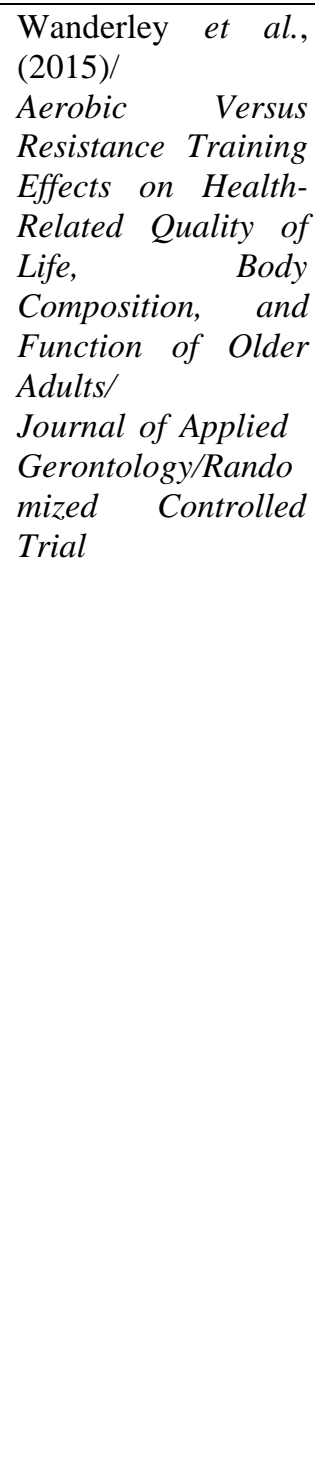 & $\begin{array}{l}\text { n=74 orang } \\
\text { Usia > } \quad 60 \\
\text { tahun dan } \\
\text { mandiri secara } \\
\text { fisik, yaitu } \\
\text { mampu } \\
\text { melakukan } \\
\text { aktivitas dasar } \\
\text { dan } \\
\text { instrumental } \\
\text { dalam } \\
\text { kehidupan } \\
\text { sehari-hari }\end{array}$ & $\begin{array}{l}\text { Group } 1(\mathrm{n}=24) \text { : } \\
\text { aerobic training } \\
\text { Group } 2(\mathrm{n}=19) \text { : } \\
\text { resistance training } \\
\text { Group } 3(\mathrm{n}=31): \\
\text { Waiting list (tidak } \\
\text { diberikan } \\
\text { intervensi apapun) } \\
\text { Masing - masing } \\
\text { intervensi } \\
\text { dilakukan selama } \\
50 \text { menit, } 3 \text { kali per } \\
\text { minggu selama } 8 \\
\text { bulan }\end{array}$ & $\begin{array}{l}\text { Primer: } \\
\text { - SF-36 } \\
\text { - Electronic } \\
\text { weight scale } \\
\text { (SECA 708) } \\
\text { - } 6 \mathrm{MWT} \\
\text { - Dynamometer } \\
\\
\text { Sekunder: } \\
\text { - Acceleromete } \\
\text { rs } \\
\text { - } 4 \text {-day dietary } \\
\\
\text { record }\end{array}$ & 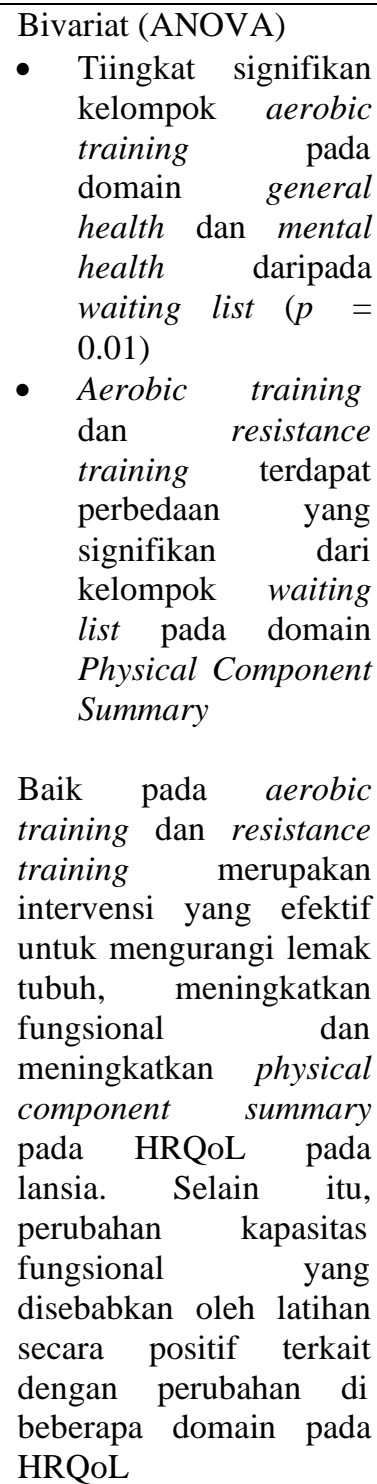 \\
\hline 2. & $\begin{array}{l}\text { Shohani et al., } \\
(2019) / \\
\text { Effectiveness of } \\
\text { aerobic exercise on } \\
\text { dimensions of } \\
\text { quality of life in } \\
\text { elderly females/ } \\
\text { Journal of Nursing } \\
\text { and Midwifery } \\
\text { Sciences/Randomize } \\
\text { d Controlled Trial }\end{array}$ & $\begin{array}{l}\mathrm{n}=60 \text { orang } \\
\text { Wanita usia } 60 \\
-70 \text { tahun } \\
\text { memiliki } \\
\text { tingkat } \\
\text { kebugaran } \\
\text { fisik dan } \\
\text { mental yang } \\
\text { memadai }\end{array}$ & $\begin{array}{l}\text { Group 1 }(\mathrm{n}=30) \text { : } \\
\text { aerobic exercise } \\
\text { dilakukan } 24 \text { sesi } \\
\text { selama } 8 \text { minggu, } 3 \\
\text { kali per minggu }(40 \\
\text { menit setiap sesi) } \\
\text { yang dibagi } \\
\text { kedalam } \\
\text { kelompok latihan } \\
\text { Group 2 }(\mathrm{n}=30) \text { : } \\
\text { kontrol, tidak } \\
\text { diberikan intervensi }\end{array}$ & - $\mathrm{SF}-36$ & $\begin{array}{l}\text { Univariat (mean) } \\
\text { Group } 1: \text { pre } 43,99, \\
\text { post } 55,46 \\
\text { Group } 2: \text { pre } 44.70, \\
\text { post } 47.31 \\
\text { Bivariat (ANCOVA) } \\
\text { - Perbedaan mean } \\
\text { sebelum dan sesudah } \\
\text { pada group } 1(p= \\
\text { 0,001) } \\
\text { - Perbedaam mean }\end{array}$ \\
\hline
\end{tabular}

July $31^{\text {th }}, 2021$ on zoom cloud meeting

Muhammadiyah University of Surakarta, Central Java, Indonesia 
Fisiomu.2021 Vol 2(3): 175-188

DOI: $10.23917 /$ fisiomu.v2i3.15203

apapun

sebelum dan sesudah pada group 2 ( $p=$ 0.41 )

- Perbedaan signifikan antara kedua kelompok $(p=0.001)$

Latihan aerobik dapat meningkatkan kualitas hidup di semua aspek mental dan fisik pada wanita berusia 60-70 tahun. Kualitas hidup mayoritas wanita lanjut usia rendah sebesar $78 \%$.

Skor rata-rata kualitas hidup pada kelompok intervensi

3. Ballin et al., (2019)/ Effects of interval training on quality of life and cardiometabolic risk markers in older adults: $a$ randomized controlled trial/ Clinical Interventions in Aging/Randomized Controlled Trial

$\begin{array}{ll}\mathrm{n}=77 & \text { Group 1 }(\mathrm{n}=38) \\ \text { Berusia } \quad 70 & \text { Aerobic training, } \\ \text { tahun dengan } & \text { dilakukan 51 menit } \\ \text { obesitas } & \text { setiap sesi, 3 kali } \\ \text { sentral } & \text { seminggu selama } \\ & 10 \text { minggu } \\ & \text { Group 2 }(\mathrm{n}=39) \\ & \text { Kontrol, tidak } \\ & \text { diberikan } \\ & \text { intervensi apapun }\end{array}$

- $\mathrm{SF}-36$

- Tensi digital

- Total cholesterol Bivariat (ANCOVA) Kelompok eksperimen mengalami peningkatan rata-rata 6,3 sedangakan pada skor MH (mental health) sebesar 6,0 jika di bandingkan dengan kelompok kontrol ( $p<$ 0.05)

Didapatkan bahwa 10 minggu latihan aerobik interval dapat disarankan sebagai intervensi tunggal untuk meningkatkan aspek mental HRQoL pada individu yang lebih tua dengan obesitas sentral, yang merupakan aspek penting dari penuaan yang sehat. Efek positif terlihat juga pada penanda risiko kardiometabolik

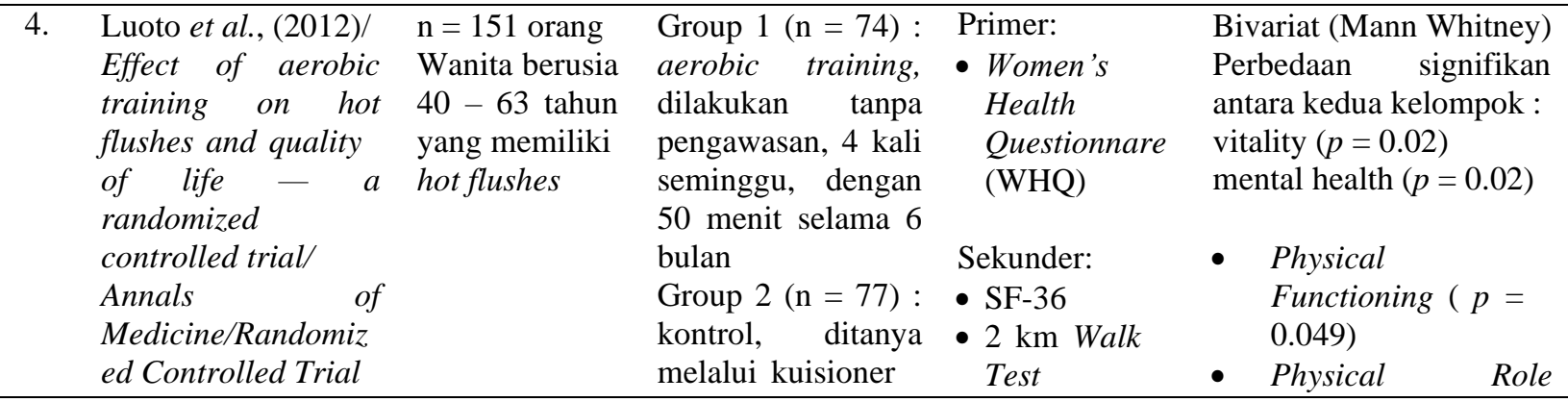

July $31^{\text {th }}$, 2021 on zoom cloud meeting Muhammadiyah University of Surakarta, Central Java, Indonesia 
S.P Pamungkas, W Munawwarah, N. K Dewi \& M Nurdesia

Fisiomu.2021 Vol 2(3): 175-188

DOI: $10.23917 /$ fisiomu.v2i3.15203

apakah sudah

mengubah aktivitas

fisik atau kebiasan

diet

\section{- Body \\ composition}

Limitation $(p=$

0.017)

- General Health $(p=$ 0.07)

Pada wanita dengan karakteristik hot flush yang tinggi (mean = 78.5)

Latihan aerobik dapat menurunkan frekuensi hot flushes dan meningkatkan kualitas hidup di antara wanita yang sedikit kelebihan berat badan

5. Shim, Choi and Shin, (2019)/

Aerobic training with rhythmic

functional

movement: Influence on cardiopulmonary

function, functional movement and Quality of life in the elderly women/

Journal Of Human

Sport \&

Exercise/Randomize

$d$ Controlled Trial

$\begin{array}{ll}\mathrm{n}=19 \text { orang } & \text { Group } 1(\mathrm{n}=9) \\ \text { Berusia }>65 & \text { Aerobic exercise }+ \\ \text { tahun, dapat } & \text { music } \\ \text { berjalan secara } & \text { Group } 2(\mathrm{n}=10) \\ \text { mandiri lebih } & \text { Aerobic exercise } \\ \text { dari 30 menit } & \\ & \text { Masing - masing } \\ & \text { kelompok } \\ & \text { melakukan } \\ & \text { intervensi 50 menit } \\ & \text { per sesi, 2 kali } \\ & \text { seminggu selama } 8 \\ & \text { minggu }\end{array}$

- SF-36

Bivariat (ANOVA)

- Spirobank -

- Perbedaan G

- FMS sebelum dan sesudah pada group 15.11 ( $p$ $<0.05)$

- Perbedaan mean sebelum dan sesudah pada group 23.70 ( $p$ $<0.05)$

- Perbedaan mean pada group 1 dan group $2(p<0.05)$

Aerobic exercise yang terdiri dari gerakan fungsional ritmis dapat meningkatkan gerakan fungsional dan kualitas hidup wanita lansia. Saat kelompok eksperimen dan kontrol kelompok dibandingkan, peningkatan kelompok eksperimen dengan musik dan ritme lebih positif daripada latihan dengan gerakan fungsional yang sama. 
S.P Pamungkas, W Munawwarah, N. K Dewi \& M Nurdesia Fisiomu.2021 Vol 2(3): 175-188

\section{Pembahasan}

Penelitian Wanderley et al., (2015) membandingkan 3 grup yaitu grup AT (aerobic training $)(\mathrm{n}=24)$ terdiri dari 10 menit pemanasan yang mencakup peregangan, senam, dan latihan intensitas rendah (berjalan dan bersepeda), dan 30 menit latihan aerobik yang sebagian besar terdiri dari walking tetapi juga termasuk stepping dan dancing, dan 10- min pendinginan. Sedangkan grup RT (resistance training) $(\mathrm{n}=19)$ terdiri dari 10 menit pemanasan yang meliputi peregangan, senam, dan latihan intensitas rendah (berjalan, bersepeda), latihan inti seperti leg press, chest press, leg extension, seated row, seated leg curl, abdominal flexion, biceps curl, low-back extension, and triceps extension untuk kelompok otot yang berbeda, dan cooldown 10 menit. Dan grup WL (waiting list) $(\mathrm{n}=31)$ tidak mendapat perlakuan apapun. Hasil intervensi Health-Related Quality of Life (HR-QOL) berupa 3 komponen yaitu General Health (GH), Mental Health (MH) dengan skor komponen mental $(\mathrm{p} \leq 0,04)$, sedangkan perubahan resistance handgrip dengan perubahan peran fisik dan $\mathrm{MH}(\mathrm{p}=.03)$. Baik pada aerobic training dan resistance training merupakan intervensi yang efektif untuk mengurangi lemak tubuh, meningkatkan fungsional dan meningkatkan physical component summary pada HRQoL pada lansia. Selain itu, perubahan kapasitas fungsional yang disebabkan oleh latihan secara positif terkait dengan perubahan di beberapa domain pada HRQoL

Shohani (2019) membandingkan kelompok intervensi aerobic exercise dengan kelompok kontrol. Kelompok intervensi dilakukan dalam 24 sesi selama 8 minggu, tiga kali seminggu (40 menit setiap sesi) dalam dua kelompok $(\mathrm{n}=15)$. Pengukuran yang digunakan adalah kuisioner quality of life (SF-36). Setiap sesi
DOI: $10.23917 /$ fisiomu.v2i3.15203

latihan terdiri dari 10 menit pemanasan up dan peregangan bersama dengan 30 menit latihan, yang dilakukan dengan metode yang tepat. Latihan terdiri dari gerakan-gerakan yang bergerak, selaras, dan berwaktu pada waktu tertentu dan terus menerus bersama dengan sebuah lagu. Pada kelompok kontrol tidak menerima intervensi apapun selama program. Mengingat pertimbangan etis setelah posttest pada kelompok kontrol, para peserta menerima aerobic. pelatihan film dan lagu untuk berolahraga di ruang olahraga pusat rehabilitasi. Selisih mean sebelum dan sesudah pada kelompok intervensi 11,47 sedangkan pada kelompok kontrol $2.62 \mathrm{p}=0.001$. Pada penelitian ini didapatkan bahwa Latihan aerobik dapat meningkatkan kualitas hidup di semua aspek mental dan fisik pada wanita berusia 60-70 tahun. Kualitas hidup mayoritas wanita lanjut usia rendah sebesar $78 \%$.

Ballin et al., (2019) membandingkan latihan aerobic training $(\mathrm{n}=38)$ dilakukan 51 menit setiap sesi, 3 kali seminggu selama 10 minggu dengan kelompok kontrol (39) tanpa melakukan intervensi. Setiap sesi didahului oleh pemanasan dengan peregangan dinamis selama 10 menit, pelatihan inti dengan hight interval training dan 5 menit relaksasi dengan peregangan statis.Hasil dari penelitian ini terjadi peningkatan secara signifikan pada score MCS (mental component summry) pada kelompok intervensi dengan ratarata 6,3 sedangakan pada skor $\mathrm{MH}$ (mental health) sebesar 6,0 jika di bandingkan dengan kelompok kontrol. Intervensi yang di berikan menghasilkan efek yang signifikan pada SF-36 di komponen MCS dan MH $(p<0.05)$. Hal ini didapatkan bahwa 10 minggu latihan aerobik high interval training dapat disarankan sebagai intervensi tunggal untuk meningkatkan aspek mental 
S.P Pamungkas, W Munawwarah, N. K Dewi \& M Nurdesia Fisiomu.2021 Vol 2(3): 175-188

HRQoL pada individu yang lebih tua dengan obesitas sentral.

Luoto et al., (2012) membandingkan kelompok 1 intervensi aerobic training $(\mathrm{n}=74)$, dilakukan tanpa pengawasan, 4 kali seminggu, dengan 50 menit selama 6 bulan. Group kontrol (n = 77), ditanya melalui kuisioner apakah sudah mengubah aktivitas fisik atau kebiasan diet. kelompok intervensi (aerobic training) memiliki skor SF-36 secara signifikan lebih tinggi dalam vitalitas $(\mathrm{P}=0,02)$ dan kesehatan mental $(\mathrm{P}=0,02)$ daripada kelompok kontrol. Perbedaan antar kelompok dalam perubahan skor SF-36 signifikan di bidang physical functioning $(\mathrm{P}=0,049)$ dan physical limitation role $(\mathrm{P}=0,017)$ dan mendekati signifikan dalam general health $(\mathrm{P}=0,07)$.

Shim, Choi and Shin, (2019) membandingkan aerobic exercise yang di tambahkan dengan music sebagai kelompok eksperimen $(\mathrm{n}=9)$ dan aerobic exercise tanpa music sebagai kelompok kontrol $(\mathrm{n}=10)$ yang dilakukan masing - masing 50 menit per sesi, 2 kali seminggu selama 8 minggu. Kedua kelompok melakukan latihan persiapan yang sama selama 10 menit pertama. Selama 30 menit latihan, kelompok eksperimen melakukan latihan aerobik dengan menghubungkan gerakan fungsional dengan musik dalam bentuk tarian sedangkan kelompok kontrol dilakukan dengan menggerakkan gerakan fungsional mengikuti irama tanpa musik. Pada kelompok eksperimen melakukan gerakan dengan musik, awalnya menggunakan musik 8-bit dan kemudian menggunakan musik 16-bit. Selain itu, minggu pertama, musik meningkat sekitar 10-15 bpm per minggu dalam musik sekitar 125 bpm (beats per menit, bpm), dan minggu terakhir sekitar 160 bpm. Hasil dari penelitian ini menyebutkan bahwa Aerobic exercise yang terdiri dari gerakan
DOI: $10.23917 /$ fisiomu.v2i3.15203

fungsional ritmis dapat meningkatkan gerakan fungsional dan kualitas hidup wanita lansia. Rerata perubahan SF-36 sebelum dan sesudah pada kelompok eksperimen adalah 5,11 $\pm 3,10$ dan kelompok kontrol adalah $3,70 \pm 1,63$, dengan $\mathrm{p}<0,05$. Temuan utama dari penelitian ini mengatakan bahwa gerakan fungsional dengan musik untuk pemulihan cardiopulmonary, gerak fungsional dan QOL lebih baik dibandingkan gerak fungsional tanpa musik pada lansia perempuan. Saat kelompok eksperimen dan kontrol kelompok dibandingkan, peningkatan kelompok eksperimen dengan musik dan ritme lebih positif daripada latihan dengan gerakan fungsional yang sama.

Seluruh literatur membahas mengenai aerobic exercise terhadap quality of life pada lansia. Aerobic exercise merupakan salah satu bentuk untuk meningkatkan kebugaran fisik yang memainkan peran yang lebih besar dalam meningkatkan penilaian diri kualitas hidup lansia. Untuk menjadi bugar secara fisik, individu harus berpartisipasi dalam beberapa bentuk aktivitas fisik yang menggunakan kelompok otot besar dan menguji sistem kardiorespirasi secara teratur. Individu dari segala usia dapat meningkatkan status kebugaran umumnya dengan berpartisipasi dalam aktivitas yang mencakup berjalan kaki, bersepeda, berlari, berenang, menaiki tangga, dengan menggunakan beban (Zeng et al., 2018).

Tingkat kebugaran dapat dijelaskan pada kontinum dari rendah hingga ke tinggi berdasarkan pengeluaran energi saat sesi aktivitas fisik. Penilaian ini biasanya berdasarkan pada pengukuran terhadap pemakaian oksigen maksimum (VO2 max) secara langsung atau tidak langsung. Konsumsi oksigen dipengaruhi oleh usia, jenis kelamin, keturunan, inaktivitas, dan penyakit. Pada sistem respirasi latihan aerobik 
S.P Pamungkas, W Munawwarah, N. K Dewi \& M Nurdesia

membuat perubahan secara cepat pada pertukaran oksigen dan karbondioksida di sepanjang membran alveolar-kapiler. Peningkatan metabolisme otot selama latihan menghasilkan lebih banyak oksigen yang di ekstraksi dari peredaran darah arteri, mengakibatkan peningkatan pada vena PCO2 dan $\mathrm{H}+$, peningkatan suhu tubuh, peningkatan epinefrin ,serta peningkatan stimulasi reseptor pada sendi dan otot. (MacInnis and Gibala, 2017).

Menurut Sławińska et al., (2013), kebugaran fisik yang lebih tinggi memberikan kontribusi yang lebih baik terhadap penilaian kualitas hidup dan kesehatan pada lansia. Akibatnya, aktivitas fisik di kalangan lansia harus fokus pertama pada peningkatan kapasitas kardiorespirasi dan kemudian kekuatan dan fleksibilitas. Selain itu, aerobic exercise yang teratur dapat meningkatkan kemandirian dan mengurangi morbiditas serta mortalitas pada lanjut usia. Penelitian ini terbatas karena menggunakan literatur yang sudah diterbitkan dan dapat diakses secara gratis.

\section{Kesimpulan dan Saran}

Dari seluruh literatur yang didapatkan disimpulkan bahwa berbagai bentuk aerobic exercise yang ada terbukti dalam meningkatkan quality of life pada lansia, berupa peningkatan pada aspek mental, fungsional dan physical component summary QoL bagi lansia.

\section{Ucapan Terimakasih}

Terima kasih kepada seluruh pihak yang telah berkontribusi dalam penyusunan penelitian ini. Selama proses penulisan dituliskan dengan kaidah etik penulisan ilmiah tanpa adanya plagiarisme. Penulisan penelitian ini bertujuan untuk memperbarui keilmuan di bidang

\section{Fisiomu.2021 Vol 2(3): 175-188
DOI: $10.23917 /$ fisiomu.v2i3.15203 \\ Fisiomu.2021 Vol 2(3): 175-188
DOI: $10.23917 /$ fisiomu.v2i3.15203}

fisioterapi sehingga tidak terdapat conflict of interest di dalam penelitian ini. Dalam proses penyusunan penelitian ini penulis menyadari bahwa penulisan ini masih jauh dari sempurna, oleh karena itu penulis terbuka untuk menerima kritik dan saran positif yang membangun.

\section{Daftar Pustaka}

Accioly, F. et al. (2013) „Aerobic versus resistance training effects on health-related quality of life, body composition, and function of older adults ${ }^{\text {ee }}$ doi: 10.1177/0733464812468502.

Ballin, M. et al. (2019) „Effects of interval training on quality of life and cardiometabolic risk markers in older adults: A randomized controlled trial ${ }^{\text {ee }}$, Clinical Interventions in Aging, 14, pp. 1589-1599. doi: 10.2147/CIA.S213133.

Doewes, M. (2009) „Exercise and brain health in elderly ${ }^{\text {ee }}$, 45(2), pp. 161-164.

Ekawati, L. et al. (2020) „Quality of Life pada Lansiae, Jurnal Ilmiah Keperawatan (Scientific Journal of Nursing), 6(2), pp. 248-251. doi: 10.33023/jikep.v6i2.648.

Fatmawati, V. and Imron, M. A. (2017) „Perilaku koping pada lansia yang mengalami penurunan gerak dan fungsiee, Intuisi: Jurnal Psikologi Ilmiah, 9(1), pp. 26-38.

Hidayati, A. R., Gondodiputro, S. and Rahmiati, L. (2018) „Elderly profile of quality of life using whoqol-bref indonesian version: a communitydwellingee, Althea Medical Journal, 5(2), pp. 105-110. doi: 10.15850/amj.v5n2.1417.

Kiik, S. M., Sahar, J. and Permatasari, H. (2018) „Peningkatan kualitas hidup lanjut usia (Lansia) Di Kota Depok Dengan Latihan Keseimbangan", 


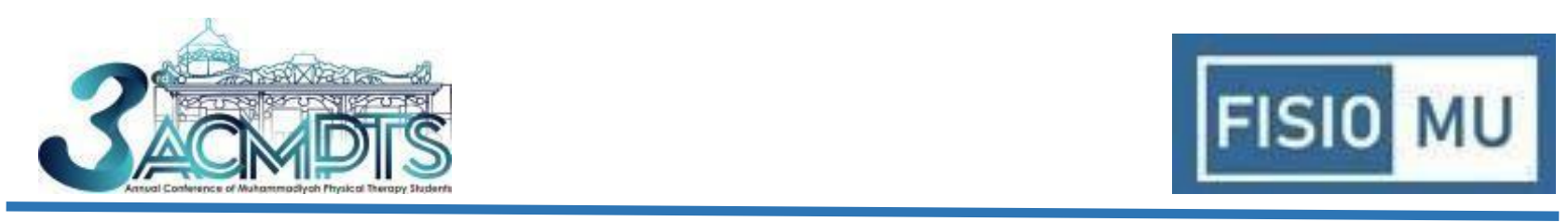

S.P Pamungkas, W Munawwarah, N. K Dewi \& M Nurdesia

Jurnal Keperawatan Indonesia, 21(2), pp. 109116. doi: $10.7454 / j k i . v 21 i 2.584$.

Knips, L. et al. (2019) „Aerobic physical exercise for adult patients with haematological malignanciese, Cochrane Database of Systematic Reviews, 2019(1). doi: 10.1002/14651858.CD009075.pub3.

Luoto, R. et al. (2012) „Effect of aerobic training on hot flushes and quality of lifea randomized controlled triale, Annals of Medicine, 44(6), pp. 616-626. doi: 10.3109/07853890.2011.583674.

MacInnis, M. J. and Gibala, M. J. (2017) „Physiological adaptations to interval training and the role of exercise intensity ${ }^{\text {ee }}$, Journal of Physiology, 595(9), pp. 2915-2930. doi: 10.1113/JP273196.

Maryani, H. And Kristiana, L. (2018) „Pemodelan angka harapan hidup ( ahh ) lakilaki dan perempuan di indonesia tahun 2016 modeling life expectancy for men and women in indonesia 2016 ${ }^{\mathrm{e}}$, Buletin Penelitian Sistem Kesehatan, 21(2), Pp. 71-81. Doi: 10.22435/Hsr.V21i2.245.71-81..

Pamungkas, M. R. (2016) „Pengaruh senam bugar lansia terhadap kualitas hidup lansia usia 60 tahun keatas di posyandu lansia karang werdha kedurus surabaya ${ }^{e e}$, Jurnal Kesehatan Olahraga, 06(2), pp. 2-5.

Ruzevicius, J. (2016) „Quality of life and of working life: conceptions and researchee, Engineering Economics, (August 2014).

Setianingsih, A. (2018) Hubungan konsep diri (citra diri) dengan kualitas hidup pasien kanker yang menjalani pengobatan di yayasan kanker indonesia cabang jawa timur surabaya. Universitas Nahdlatul Ulama Surabaya.

\section{Fisiomu.2021 Vol 2(3): 175-188
DOI: 10.23917/fisiomu.v2i3.15203 \\ Fisiomu.2021 Vol 2(3): 175-188
DOI: 10.23917/fisiomu.v2i3.15203}

Shim, Y. J., Choi, H. S. and Shin, W. S. (2019) „Aerobic training with rhythmic functional movement: Influence on cardiopulmonary function, functional movement and quality of life in the elderly women "e, Journal of Human Sport and Exercise, 14(4), pp. 748-756. doi: 10.14198/jhse.2019.144.04.

Shohani, M. et al. (2019) „Effectiveness of aerobic exercise on dimensions of quality of life in elderly femalese, Journal of Nursing and Midwifery Sciences, 6(3), pp. 149-155. doi: 10.4103/JNMS.JNMS.

Sławińska, T., Posłuszny, P., \& Rozek, K. (2013). The relationship between physical fitness and quality of life in adults and the elderly. Human Movement, 14(3), 200-204. https://doi.org/10.2478/humo-2013-0023

Suyanto, D. H., Paskaria, C. and Gunawan, D. (2021) „Perbandingan kekuatan otot dan massa otot antara wanita lansia aktif dan tidak aktif berolahragae, 4(1), pp. 9-13.

Wanderley, F. A. C. et al. (2015) „Aerobic versus resistance training effects on healthrelated quality of life, body composition, and function of older adultse, Journal of Applied Gerontology, 34(3), pp. NP143-NP165. doi: $10.1177 / 0733464812468502$.

Wilson, T. et al. (2013) Encyclopedia of Behavioral Medicine, Encyclopedia of Behavioral Medicine. doi: 10.1007/978-1-44191005-9.

Zeng, Y. et al. (2018) „Exercise assessments and trainings of pulmonary rehabilitation in COPD: A literature review ${ }^{\text {ee }}$ International Journal of COPD, 13, pp. 2013-2023. doi: 10.2147/COPD.S167098. 